\title{
A rare case of tick infestation of the eyelid: case report and literature review
}

\author{
Um caso raro de infestação de carrapatos da pálpebra: \\ relato de caso e revisão da literatura
}

Ali Riza Cenk Celebi ${ }^{1}$, Omer Orkun ${ }^{2}$

\begin{abstract}
This article presents a case of tick infestation of the lower eyelid by a previously unreported species. A 71-year-old male presented with a tick attached to the lower eyelid. The tick was identified morphologically, and then molecularly via polymerase chain reaction (PCR) and sequencing of its DNA. In addition, a review of the literature relevant to the genera of ticks associated with infestation of the human eye is provided. The tick, which was in the nymphal developmental stage, was first identified according to taxonomic keys as Dermacentor sp. For complete species identification, $16 \mathrm{~s}$ rDNA gene PCR and sequencing were performed, which showed that the tick was D. marginatus. Systematizing tick species could assist physicians in determining the potential for transmission of tick-borne human diseases.

Keywords: Tick infestations/parasitology; Eye infections, parasitic; Eyelids/pathology; Polymerase chain reaction; Base sequence; Dermacentor/parasitology; Bites and stings; Case reports
\end{abstract}

\section{RESUMO}

Este artigo apresenta um caso de infestação por carrapatos da pálpebra inferior por uma espécie previamente não declarada. Um homem de 71 anos de idade apresentou-se com um carrapato grudado na pálpebra inferior. O carrapato foi identificado morfologicamente, e, em seguida, uma estrutura molecular através de reacção em cadeia da polimerase (PCR) e a sequenciação do seu DNA. Além disso, uma análise da literatura pertinente aos gêneros de carrapatos associados à infestação do olho humano é fornecido. O carrapato, que estava em fase de desenvolvimento das ninfas, foi identificado pela primeira vez de acordo com chaves taxonômicas como Dermacentor sp. Para identificação de espécies completa, gene 16S rDNA PCR e sequenciamento foram realizadas, que mostrou que o carrapato foi D. marginatus. Sistematizando espécie de carrapato poderia ajudar os médicos a determinar o potencial de transmissão de doenças humanas transmitidas por carrapatos.

Descritores: Infestações por carrapato/parasitologia; Infecções oculares parasitarias; Pálpebras/patologia; Reação em cadeia da polymerase; Sequência de bases; Dermacentor/parasitologia; Mordeduras e picadas; Relatos de casos

\footnotetext{
${ }^{1}$ Ophthalmology Clinic, Republic of Turkey Ministry of Health, Nigde State Hospital, Turkey.

2 Department of Parasitology, Ankara University, School of Veterinary Medicine, Turkey.

The authors declare no conflicts of interests.

Recebido para publicação em 25/05/2013 - Aceito para publicação em 20/10/2013
} 


\section{INTRODUCTION}

$\mathbf{T}$ licks are acarine ectoparasites, and are among the most important vectors of human and animal diseases. Tickborne diseases are a significant threat to public health. Ticks infected with microbiological agents (primarily viruses, bacteria, and protozoa) transmit diseases to vertebrate hosts while feeding on their blood ${ }^{1,2}$. In Turkey, numerous tick species attached to humans have been reported ${ }^{3,4}$, and they transmit very serious diseases, including Crimean-Congo hemorrhagic fever, tick-borne rickettsiosis, and Lyme disease ${ }^{5-7}$. Tick infestation of the eyelid is a rare condition. Herein we report on a 71-yearold man with a tick attached to the right lower eyelid that was identified morphologically and molecularly, and a review of the literature relevant to the genera of ticks associated with infestation of the human eye.

\section{Case presentation}

A 71-year-old man with a two-day history of a small gray lesion on the medial aspect of the lower right eyelid presented to Nigde State Hospital, Ophthalmology Clinic with itching and localized redness caused by tick infestation. He was a farmer from a rural region and had contact with farm animals, which we considered was the likely source of tick infestation. Ophthalmologic examination showed a two millimeter elevated light gray lesion compatible with a tick on the medial aspect of the right lower eyelid (Figure 1). The head of the tick was embedded in the skin of the eyelid and its body moved during manipulation with tweezers. The remainder of the eye examination, including visual acuity and anterior segment examination, was normal. The patient did not have any systemic symptoms at presentation.

The tick was successfully removed using tweezers. The patient's blood was drawn to screen for thrombocytopenia; the platelet count was normal at presentation and one month later. During follow-up, one week post presentation, erythema of the lower eyelid was found to have subsided without the use of topical medication. The tick was sent to the laboratory of the School of Veterinary Medicine, Protozoology and Entomology at Ankara University for further investigation and identification. The tick, which was in the nymphal developmental stage, was identified according to taxonomic keys ${ }^{8}$ as Dermacentor sp. For complete species identification16s rDNA gene PCR and sequencing were performed ${ }^{9}$, which showed that the tick was $D$. marginatus.

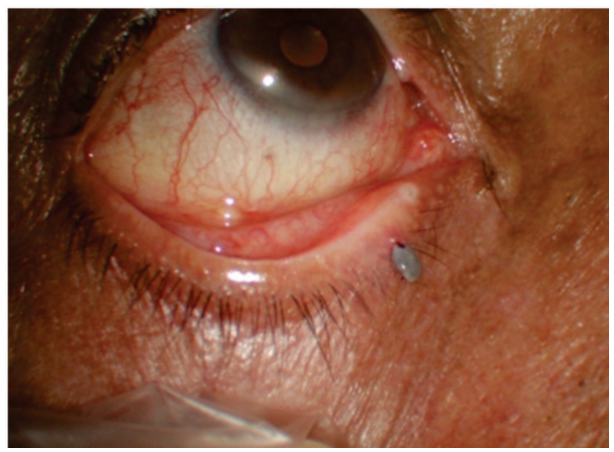

Figure 1: D. marginatus attached to the medial aspect of the patient's right lower eyelid.

\section{DisCUSSION}

Ticks embedded in the meibomian gland orifice or in the eyelash margin generally manifest as a mass on the eyelid margin. The most frequent symptomatic eye manifestations are conjunctivitis, uveitis, keratitis, and vasculitis ${ }^{10}$. The genera of ticks that have attached to human eyelids have been described previously: the nymphal form of $D$. auratus was the first documented tick embedded in the human eyelid ${ }^{11}$; Hara et al. reported Ixodesovatus Neumann in a 30-year-old female‘s right superior eyelid ${ }^{12}$; Santos-Bueso et al. reported Rhipicephalus sanguineus for the first time in a 21-year-old female's right upper eyelid ${ }^{10}$; Samaha et al. reported a nymphal stage tick of the genus Hyalomma, but of an unspecified species in a 58-year-old female's left upper eyelid margin ${ }^{13}$; and McLeod described I. ricinus in an 11-month-old girl and reported that I. ricinus was the most common tick in Scotland, Wales and the West of England ${ }^{14}$.

Bodé et al. reported that in addition to human eyelids, tick infestation can occur in conjunctival tissue; they identified a tick embedded in the conjunctiva as the larval form of Amblyomma americanum $^{15}$. Singh et al. reported an 11-year-old girl living in an urban region of Singapore with Ixodessp. infestation of the upper eyelid; however, despite the fact that ticks are more common in rural environments, they reported that tick infestation of the eyelid can occur in urban regions ${ }^{16}$. Liolios et al. reported a 40year-old female in England with a tick of the Ixodesgenus on her left lower eyelid, without any other ophthalmological findings ${ }^{17}$.

Ticks must be removed as soon as possible, as animal and human studies have shown that the risk of disease transmission increases after 24 hours of attachment and increases significantly after 48 hours $^{18}$. Holak et al. reported Lyme borreliosis in 1 of 5 patients diagnosed with left abducens nerve palsy following Ixodes genus infestation of the eyelid region ${ }^{19}$. Keklikci et al. reported another tick described as I. ricinusin in a three-yearold girl's right upper eyelid margin. They advised removing such ticks as soon as possible via mechanical procedures to prevent disease transmission ${ }^{20}$. While a tick is attached, or after its removal, an inflammatory reaction leading to abscess formation or secondary infections may occur ${ }^{18}$. Sakalaret al. reported on a four-year-old girl with cellulitis due to infestation by the nymphal form of a tick of the Ixodes genus ${ }^{21}$.

It is important to know that ticks can produce one or more toxins that cause tick paralysis by blocking the neuromuscular system. Symptoms can be local, such as facial nerve paralysis, or systemic. Commonly, there is an ascending flaccid motor paralysis that occurs within hours or up to a few days after tick bites. The paralysis usually progresses to respiratory failure and even death. Almeida et al. described tick paralysis in a 28 -year-old male due to immature stages of ticks, probably of the Amblyomma genus. Their patient had shown loss of muscle strength, decreased reflexes, and marked palpebral ptosis. The ticks were removed individually, and the patient's ptosis improved six hours after the last tick was removed. The following day there was near total regression of manifestations. The researchers recommended that all cases of suspected tick paralysis should be promptly diagnosed and treated ${ }^{22}$.

Tick paralysis has been described in Turkey: Gürbüz et al. reported a three-year-old girl with facial palsy caused by Hyalomma marginatum ${ }^{23}$; Engin et al. described tick paralysis with atypical upper trunk involvement of the brachial plexus in a 66 year-old male farmer ${ }^{24}$; and Doðan et al. reported a case with peripheral facial nerve paralysis due to a tick of the genus 
Hyalomma attached to the external auditory canal ${ }^{25}$. It is also important to know that D. marginatus can also cause tick paralysis: Abdigoudarzi et al. described tick paralysis in a 48-year-old female in Iran caused by D. marginatus ${ }^{26}$.

In Turkey, D. marginatus ticks are known to transmit the following disease pathogens to humans: Rickettsia slovaca and $R$. raoultii, which cause TIBOLA/DEBONEL (tick-borne lymphadenopathy/ Dermacentor-borne necrosis erythema and lymphadenopathy) ${ }^{7}$, and Crimean-Congo hemorrhagic fever virus $^{27}$. In addition, Coxiellabrunetti, Omsk hemorrhagic fever virus, $R$. sibirica subsp. sibirica, and Francisellatularensis are transmitted by $D$. marginatus ticks, but such transmission has yet to be observed in Turkey.

Tick infestation of the human eyelid is rare. Systematizing the species of ticks that attach to the eyelid can alert physicians to the potential for transmission of the above-mentioned disease pathogens. Timely mechanical removal of ticks is an easy, safe, and effective method of preventing tick-associated systematic and local ocular complications.

\section{ReFERENCES}

1. Sonenshine DE. Biology of ticks. Oxford: Oxford University Press; 1991. p. 447-50.

2. Estrada-Peña A, Jongejan F. Ticks feeding on humans: a review of records on human-biting Ixodoidea with special reference to pathogen transmission. Exp Appl Acarol. 1999;23(9):685-715. Review.

3. Karaer Z, Guven E, Nalbantoglu S, Kar S, Orkun O, Ekdal K, et al. Ticks on humans in Ankara, Turkey. Exp Appl Acarol. 2011;54(1):85-91.

4. Vatansever Z, Gargili A, Aysul NS, Sengoz G, Estrada-Peña A. Ticks biting humans in the urban area of Istanbul. Parasitol Res. 2008;102(3):551-3.

5. Ergönül O. Crimean-Congo haemorrhagic fever. Lancet Infect Dis. 2006;6(4):203-14. Review.

6. Güner ES, Hashimoto N, Takada N, Kaneda K, Imai Y, Masuzawa T. First isolation and characterization of Borrelia burgdorferi sensu lato strains from Ixodes ricinus ticks in Turkey. J Med Microbiol. 2003;52(Pt 9):807-13.

7. Orkun O, Karaer Z, Çakmak A, Nalbantoðlu S. Spotted fever group rickettsiae in ticks, Turkey. Ticks Tick Borne Dis 2013. In press.

8. Estrada-Pena A, Bouattour A, Camicas JL, Walker AR. Ticks of domestic animals in the Mediterranean region. In: Estrada- Pena AA. Guide of identification of species. Zaragoza: Zaragoza University press; 2004a. p.131-2.

9. Black WC 4th, Piesman J. Phylogeny of hard- and soft-tick taxa (Acari: Ixodida) based on mitochondrial 16S rDNA sequences. Proc Natl Acad Sci U S A.1994;91(21):10034-8.

10. Santos-Bueso E, Calvo-González C, Díaz-Valle D, Benítez-delCastillo JM, García-Sánchez J. [Eyelid tick bite]. Arch Soc Esp Oftalmol. 2006;81(3):173-5. Spanish.

11. Kirwan EO. A Tick on the upper eye-lid (Dermacentor auratus nymph). Br J Ophthalmol. 1935;19(12):659-61.
12. Hara S, Takei Y, Shiga N. A case of tick bite. Jpn J Ophthalmol.1982;26(3):308-13.

13. Samaha A, Green WR, Traboulsi EI, Ma'luf R. Tick infestation of the eyelid. Am J Ophthalmol. 1998;125(2):263-4.

14. McLeod BK. Sheep tick in the eyelid. Br J Ophthalmol. 1986;70(1):75-6.

15. Bodé D, Speicher P, Harlan H. A seed tick infestation of the conjunctiva: Amblyomma americanum larva. Ann Ophthalmol. 1987;19(2):63-4.

16. Singh M, Gopalakrishnakone P, Yeoh RL. Ixodes tick infestation of the eyelid of a child. Can J Ophthalmol. 2006;41(6):783-4.

17. Liolios V, Goldsmith C. Tick infestation on the lower eyelid: a case report. Cases J. 2009;2:9073

18. Gammons M, Salam G. Tick removal. Am Fam Physician. 2002;66(4):643-5. Review.

19. Holak H, Holak N, Huzarska M, Holak S. Tick inoculation in an eyelid region: report on five cases with one complication of the orbital myositis associated with Lyme borreliosis. Klin Oczna. 2006;108(4-6):220-4.

20. Keklikçi U, Unlü K, Cakmak A, Akdeniz S, Akpolat N. Tick infestation of the eyelid: a case report in a child. Turk J Pediatr. 2009;51(2):172-3

21. Sakalar YB, Arserim NB, Keklikci U, Balsak S, Alakus MF, Unlu K. Kene Enfestasyonuna Baðlý Preseptal Selülit. TJO 2010;40(5):307-9.

22. Almeida RA, Ferreira MA, Barraviera B, Haddad Jr V. The first reported case of human tick paralysis in Brazil: a new induction pattern by immature stages. J. Venom. Anim. Toxins Incl Trop Dis. 2012;18(4):459-61.

23. Gürbüz MK, Erdoðan M, Doðan N, Birdane L, Cingi C, Cingi E. [Case report: isolated facial paralysis with a tick.]. Turkiye Parazitol Derg. 2010;34(1):61-4. Turkish.

24. Engin A, Elaldi N, Bolayir E, Dokmetas I, Bakir M. Tick paralysis with atypical presentation: isolated, reversible involvement of the upper trunk of brachial plexus. Emerg Med J. 2006;23(7):e42.

25. Doðan M, Devge C, Tanrýöver O, Pata YS, Sönmezoðlu M. Facial nerve paralysis due to intra-aural Hyalomma tick infestation. Turkiye Parazitol Derg. 2012;36(4):254-7.

26. Abdigoudarzi M, Belgheiszadeh $\mathrm{H}$, Shariati N. Tick paralysis in human; a case report. Iran J Clin Infect Dis. 2006;1(3):159-60.

27. Gargili A, Midilli K, Vatansever Z, Ergin S, Deniz A, Selek Aysul $\mathrm{N}$, et al. A survey of Crimean-Congo haemorrhagic fever virus in tick populations and wild-life animals in Turkey [abstract]. In: 18th European Congress of Clinical Microbiology and Infectious Diseases; 2008 April 19-22; Barcelona, Spain.

\section{Corresponding author:}

Ali Riza Cenk Celebi

Republic of Turkey Ministry of Health, Nigde State Hospital,

Ophthalmology Clinic,

Feridun Zeren Street, 51000 Nigde,

Tel: +9038823222 20 - 159

E-mail: arcenkcelebi@gmail.com 